\title{
Puisi dan Pemanggungan ${ }^{1}$ Oleh Teguh Trianton ${ }^{2}$
}

Puisi adalah hasil sublimasi nilai kehidupan dalam timbunan bahasa. Puisi pertama kali merupakan karya seni yang dibangun menggunakan sistem tanda verbal sebagai mediumnya. Dengan medium bahasa verbal, puisi memuat beragam gagasan, wacana atau diskursus, bahkan ideologi. Puisi mengendapkan berbagai ide, pengalaman, pandangan, bahkan cara hidup penyair atau orang di sekitarnya.

Puisi, sesungguhnya adalah teks. Ia bukan sesuatu yang tertulis, tetapi sesuatu yang ada di balik tulisan. Yang ditulis oleh penyair adalah kata-kata, membentuk kalimat, menjadi alinea, bait atau paragraf. Tetapi, apa yang dimaksudkan oleh penyair berada di balik itu semua. Puisi memeram wacana yang bersifat laten.

Sebagai sebuah teks, puisi diciptakan dengan perspektif yang cenderung primordial dan subjektif. Ia ditulis menurut gaya khas sang penyair. Itulah sebabnya puisi memiliki ideosinkrasi, baik dalam bahasa maupun bahasannya. Ia merepresentasikan pribadi penyair dalam merespon fenomena. Ia dapat menjadi alter ego penyair.

\section{Puisi Dibaca}

Puisi boleh jadi hanya catatan sekaligus pesan pribadi penyair mengenai berbagai persoalan. Terdapat ego di dalamnya. Meski demikian, penyair menyadari bahwa puisi yang dia tulis memiliki alamat yang dituju. Oleh karena itu, penyair tidak mungkin berlaku egois dalam memanfaatkan sistem tanda yang ia padatkan. Penyair mesti memberikan celah untuk masuk bagi pembaca agar dapat memahami sesuatu yang dimaksud.

Pada wilayah proses kreatif, isi dalam puisi sepenuhnya merupakan hak otonom penyair. Tatkala puisi dibaca oleh liyan maka terjadi pengalihan hak dan otonomi pengolahan pesan. Di hadapan pembaca pertama, isi puisi sepenuhnya menjadi haknya. Makna dalam puisi direbut melalui prosedur rekuperasi dan interpretasi.

Liyan sebagai pembaca pertama memanfaatkan celah di antara kepadatan sistem tanda sebagai pintu untuk memasuki ruang-ruang puisi. Selanjutnya liyan akan membongkar kepadatan semiotik menjadi ruang terbuka. Di tempat itulah liyan bebas membangun interpretasi bagi dirinya sendiri.

Pembongkaran semiotik ini dilakukan secara laten melalui dialog yang intensif. Liyan berupaya melakukan konfirmasi teks yang ia miliki terhadap struktur wacana puisi dengan memperhatikan berbagai konteks. Proses inilah yang sering disebut sebagai hubungan intertekstual. Penjaringan teks dilakukan secara simultan untuk mendapatkan makna yang paling presisi.

\section{Puisi Dibacakan}

Pembacaan puisi di pentas merupakan salah satu wujud apresiasi. Pentas baca puisi selama ini diyakini sebagai salah satu cara untuk menjembati komunikasi pesan antara penyair dengan audien (penonton). Namun, puisi yang dibaca di atas pentas sebenarnya telah kehilangan otonominya sebagai teks yang terbuka. Penonton tidak memiliki koneksi langsung dengan puisi yang ditulis penyair. Pemahaman teks sangat bergantung pada kemampuan aktor dalam menafsir ulang puisi yang dibaca, dan kemampuan penonton memahami tafsir sang aktor.

Pembongkaran tanda pada puisi sangat rentan menimbulkan kekeliruan interpretasi. Puisi yang dibacakan oleh liyan sebagai aktor untuk audien telah melewati 
proses modifikasi sistem tanda. Aktor berpotensi melakukan dua hal sekaligus. Ia dapat menerangkan dan memanipulasi pesan secara simultan melalui intonasi, jeda, ekspresi, gestur, dan unsur metalinguistik lainnya.

Jika penonton berupaya menginterpretasi puisi yang dibaca oleh aktor di atas pentas, maka mereka sesungguhnya bukan menginterpretasi puisi yang ditulis oleh penyair. Mereka yang menonton pentas baca puisi sesungguhnya tengah berupaya memahami bagaimana cara aktor menginterpretasi puisi dan mengartikulasikan untuk penonton. Di sinilah titik lemah proses pertukaran teks yang melibatkan audien, pembaca, dan penyair.

Kondisi ini tentu berbeda jika puisi yang dibacakan langsung oleh penyairnya. Penonton akan mendapatkan peta jalan masuk yang paling original untuk menembus ruang puisi. Penyair menunjukan jalan melalui artikulasi puisinya sendiri. Meski demikian tidak ada garansi bahwa pembacaan puisi ini terbebas dari miss-interpretasi. Lantaran pemaknaan puisi sesungguhnya ditentukan oleh kemampuan penonton mengelola jejaring teks yang dimiliki dengan teks puisi dalam berbagai konteks.

\section{Puisi Dipanggungkan}

Pemanggungan puisi sebenarnya merupakan bentuk alih wahana yang dilakukan dalam rangka membuka ruang pemaknaan yang lebih luas. Pemanggunggan puisi lazim dilakukan dalam bentuk dramatisasi, teatrikalisisi, dan musikalisasi. Pada wahana yang lebih mutakhir, puisi juga lazim didaptasi menjadi film, lukisan, atau tarian.

Puisi yang dipanggungkan tentu saja telah kehilangan originalitasnya. Puisi tidak lagi tampil lugu dengan mengandalkan daya bahasa verbal. Puisi mengalami metamorfosa. Ia telah beralih wujud menjadi karya seni lain yang lebih rumit melalui penambahan berbagai sistem tanda. Unsur puisi memang tetap melekat di dalamnya, tetapi ia bukan lagi puisi seperti yang dimaksud oleh penyairnya.

Yang lahir kemudian adalah bentuk karya seni baru. Sementara puisi yang dimaksud oleh penyairnya telah lebur. Ia benar-benar menjadi teks yang tersimpan sebagai referensi. Ia hanya akan dipanggil lagi jika benar-benar dibutuhkan dalam proses interpretasi oleh penonton.

Pemanggungan puisi berpotensi mendistorsi pesan atau makna yang dikehendaki oleh penyairnya. Tetapi, pada saat yang sama, ia bisa menjadi lebih kaya dan lebih mudah dipahami oleh audien. Pemanggungan puisi yang baik akan memberikan ruang yang lebih luas dan terbuka terhadap berbagai diskursus. Lalu lintas pesan tidak melulu ditentukan oleh unsur intrinsik puisi.

Penonton mendapat sokongan besar dari penggunaan sistem tanda yang bertingkat dalam proses pemanggungan puisi. Aransemen musik, tata lampu, dramaturgi, tata busana, pemilihan warna, dan sistem tanda lain turut merekonstruksi makna puisi menjadi sesuatu yang relatif baru. Dalam konteks ini, puisi tidak lagi menjadi objek literasi tunggal. Ia harus dibaca dengan cara yang berbeda. Penonton harus menempatkannya menjadi objek multileterasi.

$* * *$

\footnotetext{
${ }^{1}$ Artikel ini pertama terbit di kolom Bahasa, Sastra, dan Budaya Harian Rakyat Sultra, edisi Senin, 18 Februari 2019, halaman 4.

${ }^{2}$ Penikmat Puisi, Peneliti Beranda Budaya (Purwokerto), Mengajar di Prodi PBSI FKIP UMP Purwokerto.
} 